\title{
Capital Structure And Corporate Financial Performance: Evidence From Nigerian Cement Companies
}

\author{
Prof. M 0. Ogbulu \\ Department of Banking \& Finance, Abia State University, \\ Uturu, Nigeria \\ Sunday Ukeje Okanta Ph.D \\ Department of Banking \& Finance, Abia State University, \\ Uturu, Nigeria \\ Morrison J. Turakpe \\ Department of Banking \& Finance, Ken Saro-Wiwa Polytechnic, Bori, \\ Rivers State, Nigeria
}

\begin{abstract}
This study seeks to examine the impact of capital structure on corporate financial performance of four cement companies in Nigeria for the period 2006 - 2015. Data selected as proxies for the financial performance of the firms, which included return on asset (ROA), return on equity (ROE), and return on sales (ROS) were generated from the firm's audited annual financial reports. Data on total debt/asset ratio (TDA), longterm debt/asset ratio (LDA), and equity/asset ratio (EQA) were selected as proxies for capital structure of the firms. Also, data on asset-turnover ratio (ATO) (measurement for asset utilization), total asset (TAST) and total sale (TSAL) - measurements for firm size, were selected as control variables. The parameters of the above variables were estimated using Autoregressive Distributed Lag (ARDL) method. The result of the study revealed that all the capital structure variables (TAD, LDA and EQA) have mixed impact on financial performance indicators (ROA, ROE and ROS) used in the study. While there existed positive relationships between the control variables of ATO, TAST and performance, TSAL negatively related to financial performance measures. Following from the findings of the study, corporate decision makers in Nigerian cement industry should be careful in the use of debts. While it is necessary to use debt as a source of finance, such a decision should be a last option as supported by the Pecking order theory. Rather, retained earnings should be preferred.
\end{abstract}

Key Words: Capital Structure, Corporate Financial Performance, Cement Companies, Return on Assets, Return on Equity, Return on Sales

\section{Background of the Study}

\section{INTRODUCTION}

Corporate financing decision, one of the four major corporate finance decisions (others include investment, dividend and liquidity decisions), are quite complex processes. Theories in corporate finance may only have explained certain facets of the diversity and complexity of financing choices. Researches over the years have given no accepted conclusion on the exact determinants and relationship between capital structure and firm performance in either developed or emerging economies. Graham and Harvey (2001) argued that, although a lot of studies have been done in investigating capital structure of the firms, the results obtained are still unclear. This, according to them, might be due to wrong measurement of key variables, investigation on wrong models or issues, misspecification of managerial decision process or unresponsiveness of owner-managers. Capital structure is very important for firms because it has an impact on long-term corporate profits, firm's valuation and capital budgeting decisions 
(Aurangzeb and Hag, 2012). It represents the firm's financial framework which consists of the debt and equity used to finance the firm. Decisions regarding types of capital structure of a firm should play a critical role since capital impacts on profitability and solvency.

An optimum capital structure which gives maximum returns to shareholders plays an important role in the growth and progress of any company. As in Singh and Singh (2016), Solomon and Weston (1973) posit that the proper and right combination of debt and equity will always lead to a market value enhancement. In making capital structure decisions managers should consider the significant difference between the industry and the individual companies within an industry. Two similar companies can have different capital structures as per the different judgement of decision makers with the significance of various factors.

Capital structure is the combination of debt and equity that finance the firm's strategic plan. Gitman (2009) emphases that capital structure policy is a policy concerning the optimal combination of the use of external and internal sources of funds to finance an investment and also to support the company's operations in an effort to increase its profits and achieve a higher value. It is important to have optimal combination of funds from internal and external sources in the firm's capital structure to avoid a highly leveraged firm, with maximum debt source of finance in its capital structure which results in the firm finding its freedom of action restricted by its creditors and may have its profitability affected with the payment of higher interest costs.

The problem that financial managers are faced with in capital structure decisions is that there is yet no clear cut guideline that can be consulted when taking decisions regarding optimal capital structure. An optimal capital structure enhances the competency of the firm and impacts higher returns to shareholders compared to the return provided by an all equity firm. Akinsurile (2008) argues that most financial managers make capital structure decisions not necessarily out of empirically verified evidence. Myers (2001) asserts that large number of business failures in the past have been due to the inability of the financial managers to correctly identify and take advantage of the economical sources of financing for their firms based on empirically verified information.

Various theories in business finance on capital structure, starting with the Modigliani and Miller (1958) theorem (commonly referred to as $M$ \& $M$ Theorem), have generated considerable debates due to their inherent controversies, making the issue to be more complex. Modigliani and Miller in their "theory of irrelevance" had hypothesized that in a world of frictionless capital market; there would be no optimal financial structure. In M\&M's over-simplified world, no capital structure mix is better than the other.

Studies on capital structure are mostly carried out in developed countries. Only few studies have been conducted in developing countries including Nigeria. The cement industry in Nigeria is an important sector that is yet to be given special importance in the capital structure study. Few studies on the cement industry in Nigeria used variables like long-term debt and shortterm debt to find the relationship between capital structure and profitability (profitability as proxy by return on equity and return on assets). In this study, an attempt is made to find the impact of capital structure on corporate profitability by adding new variables like return on sales, total debt to total fund, and equity to total fund ratios.

\section{Statement of the Problem}

Various studies over the years have not agreed on the extent of the impact of capital structure on the financial performance of firms in either developed or developing economies. Myers 
(2001) and Abor (2005) have noted that the inability of the financial managers to painstakingly evaluate and take advantage of economical resources of financing for their firms based on empirically verified information and the effect of such resources of financing on the profitability of their firms, had led to the failure of many organisation in the past. This discovery may have led to another study by Jensen and Meckhing (2011) which posited that the criteria some financial managers use in practice to make capital structure decisions are not based on empirically- proven principles; rather they use impressive rules of thumbs for identifying sources of financing, resulting to distress and collapse of such firms in the long run.

Capital structure theories, such as trade-off, pecking order and agency cost theories have been developed to explain capital structure, but the problem of optimal capital structure is still one of the central problems of corporate finance and has attracted much attention as a research fertile area (Noulas and Genimakis, 2011 and Olayinka, 2011). For these many years researchers have studied the impact of capital structure on firm's performance, they still cannot agree on the extent of the impact. In some countries like Nigeria, investors and stakeholders do not look in detail the effect of capital structure in measuring their firm's performance as they may assume that attributions of capital structure are not related to their firm's value (San and Heng, 2011). In Nigeria, the cement industry presents a veritable ground for us to look at their capital structures and the impacts on their corporate performances. This emanates from the fact that the industry has maintained sustainability in business over the years despite the economic woes that continued to face the country.

Although there are existing theoretical frameworks from finance and strategic management set out to explain the determinants of capital structure and the impact of capital structure on firm financial performance, there is still no agreement among economists and other researchers in finance as to which of the existing theories present the best description of the actual behaviour of firms. With the mixed and conflicting results from various studies, the quest for examining the relationship between capital structure and firm performance has remained a 'puzzle' and empirical study continues.

\section{Objectives of the Study}

This study is intended to contribute to the on-going debate on the subject matter of capital structure and corporate financial performance. Specifically, the objectives are:

- To find out if there is a positive relationship between capital structure and financial performance of cement companies in Nigeria.

- To examine the theoretical/conceptual issues in firm capital structure mix with particular reference to cement industry in a developing country.

\section{Research Hypothesis}

The following hypotheses are stated to direct the study.

- There is a positive relationship between total debt and financial performance of cement companies in Nigeria.

- There is a positive relationship between long-term debt and financial performance of cement companies in Nigeria.

- There is a positive relationship between equity and financial performance of cement companies in Nigeria.

\section{Significance of the Study}

This study will be of significance to stakeholders - investors, supplies, management and shareholders - in the cement industry . It will be of significance to owners of cement companies 
in the design of optimum capital structures, to suppliers in assessing the credibility of the firms, to shareholders in assessing the firms' financial risks, to the management in taking financial decisions, and to the investors in investing in leveraged firms. The study can guide policy makers in the cement industry in Nigeria in the formulation of appropriate policies that will enhance the growth of the industry.

\section{Organization of the study}

Following section one (introduction) the rest of the study is structured as follows: Section two briefly reviews related literature of the study. The section sets out the theories and empirics on the relationship between capital structure and financial performance of corporate organisations; section three discusses the research methodology including model specification, while section four focuses on data presentation, analysis and discussion of empirical results. Lastly, section five concludes the study with recommendations and remarks and acknowledgement.

\section{Conceptual Framework}

\section{LITERATURE REVIEW}

Capital structure refers to the way a firm finances its overall operations and growth by using different sources of funds composed of long-term debt, specific short-term debt and equity. A firm's capital structure in reality is the composition of its liabilities. The choice of a firm's capital structure is an important decision to make not only from a returns maximization point of view, but also because this decision has a great impact on a firm's ability to successfully operate in a competitive environment (Shamshur, 2012). The different cost of each component of capital structure to a firm makes its decision to be critical because it may affect the firm's value. The purpose of managing capital structure is to mix the financial resources in order to maximize the wealth of shareholders and minimize the company's cost of capital (Ross et al, 2005). Making a wrong mix of finances employed in the firm might seriously affect the performance and survival of the business enterprise. It is therefore imperative that a company should plan an optimum capital structure to ensure the balance between risk and return in order to maximize the stock price.

A performance measure of an organisation is a controversial issue in finance due to its multidimensional nature. Such measures like profit maximization, maximization of sales and maximization of shareholders' benefit are at the core of the firm's effectiveness (Murphy et al, 1996 and Chakronvarthy 1986). Hoffer and Sandberg (1987) establish that operational performance measures, such as growth in sales and growth in market share, provide a broad definition of performance as they focus on factors that ultimately lead to financial performance. In literature, the most commonly used financial performance measures/proxies are return on assets, return on equity, or return on investment (Cole and Lin, 2000). The determination of an optimum capital in practice is a formidable task, and it goes beyond theory. The questions researchers are still trying to find answers to include whether the firm should go for debt or equity finance at the time of requirement and how much debt and equity the company should take? Does timing the markets for raising capital play an important role or not? The capital structure decision is a continuous process and any change in its pattern affects the debt-equity mix, which in turn influences the cost of capital and consequently, affects the value of the firm.

\section{Theoretical Framework}

The composition of capital structure depends on several external and internal factors, like the line of business, economic conditions, and the firm's strategy. Firms with low credit rating tend to have a multi-tied capital structure consisting of different types of debts, while higher rated 
firms use fewer layers (Rauth and Sfulz, 2010). The theory of capital structure was first developed by Modigliani and Miller (1958). M\&M Theory assumes that the market is perfect and everyone in the market has perfect information, and no one individual (or company) can influence the price; there is a single rate of interest for borrowing and lending; there are no homogeneous products; there exist investors who are rational; and there is no personal or corporate taxation. These assumptions have generated more researches by scholars since $\mathrm{M} \&$ M theory predicted $100 \%$ debt financing (due to substantial corporate tax benefit), which is not observed in practice.

M\&M theoretical proposition carries the implications that: (1) financing and investment policies are independent, (2) internal and external financing are perfect substitutes; and (3) the specific type of the financing contractual arrangement, either equity or debt, is also irrelevant (Marques and Santos, 2003). Later, Modigliani and Miller (1963) published a correction of their article due to an error found in the "discussion of the effects of the present method of taxing corporations on the valuation of firms". When tax was introduced into their model, it was found that the value of a firm increases with more debt due to the tax shield. The tax advantage of debt financing was therefore proven to be greater than expected in Modigliani and Miller (1958). M\&M (1958), based on their assumptions, had argued that the capital market is perfect and that debt and equity are perfect substitutes of each other. The implication of their position is that in this perfect market, financial decisions are irrelevant and there is no financial leverage. This means that the way organisations are financed is irrelevant.

According to Kraus and Litzenberger (1973), the prefect capital market does not exist in the real world, which makes the choice to finance with debt or equity important for organisations. Practically, this implied that the value of an organisation varies with changes in their capital structure and that the imperfections in the capital market influence the financing decisions.

The trade-off theory, the pecking order theory and the agency cost theory show that the classical theory of Modigliani and Miller (1958) is unrealistic. These theories show that debt and equity are no perfect substitutes of each other, as Modigliani and Miller (1958) stated and that the decisions of the capital structure are important for organisations (Hillier, et al, 2010).

The trade-off theory of capital structure states that an organisation's capital is constituted by both debt and equity and that their ratio (debt-equity ratio) is a trade-off between its interest tax shields and the costs of financial distress. The theory states that there is an advantage of financing through debts due to tax benefit of the debts. However, some costs such as debt costs, bankrupt costs and non-bankrupt costs do arise. The tax benefit, among other factors, makes the after-tax cost of debt lower and hence the weighted average cost of capital (WACC) will also be lower (Anarfor, 2015). Brigham and Gapenski (1996) argue that an optimal capital structure can be if there exists tax benefit which is equal to bankruptcy cost. According to the theory, the idea is that as the debt-equity (D/E) ratio increases then there is a trade-off between bankruptcy and tax shield and this as a result, causes an optimal capital structure for the firm. Despite the theoretical appeal of debt financing, researchers of capital structure have not found the optimal capital structure (Simerly \& Li, 2000).

The pecking-order theory of capital structure developed by Myers (1984) and Myers and Majluf (1984) is of the essence that firm will adhere to the hierarchy of financing by preferring to finance itself from internally generated funds, because the use of such funds does not send any negative signal that may lower the stock price of the firm. When internal finances are depleted, it will opt for equity (Anarfor, 2015). The assumption of this theory is that firms will 
always follow the hierarchy of financing through internal funds and finally as a last resort, finance through equity which may not be true in practice. Myers and Majluf further postulate that firms that make high profits tend to attain low debt profile because when firms are more profitable their first priority is to generate financing through retained earnings since they maximize the value of the existing shareholders. The pecking-order theory suggests that organisations well understand their financial resources and give priority according to their existing working situation (Aurangzeh and Haq, 2012). The theory is a competing theory of capital structure that says that firms prefer internal financing.

Another theory which gives explanation to how organisations select their capital structure is the Agency Theory by Jensen and Meckling (1976). According to these authors, managers (the agents) do not always pursue shareholders' interest (the principals). They suggest that firms should either increase the ownership of the managers in the firm in order to align the interest of managers with that of the owners or increase the use of debt which will reduce the equity base and thus increase the percentage of equity owned by managers. Boodhood (2009) posits that the advantage of agency cost theory is that leverage firms are better for shareholders as debt can be used to monitor managerial behaviour. A control mechanism which can be used to checkmate the managers' excesses to pursue the firm's overall goals, according to Chechet and Olayiwola (2014), is the introduction of more leverage in financing the firm. Chechet and Olayiwola assert that from the postulation of the agency cost theory, if more debt is employed, the threat of liquidation, debt servicing, which may eventually result to loss of jobs to the managers, will result to cost reduction thereby leading to efficiency and subsequently enhancing firm and managerial performance.

\section{Empirical Literature}

Numerous studies have been conducted on the impact of capital structure on firms' financial performance using empirical test to explain how firms chose between debt and equity and their relative proportion in firm financing. As established and cited in Anarfo (2015), some studies have concluded that the relationship between capital structure and firm performance is both positive and negative; others concluded that the relationship is negative. Yet, other studies have documented a positive relationship. These mixed and conflicting results of capital structure and firm performance is Myer's (1993) argument that it is a PUZZLE and mirrored by Stiglitz and Weiss (1981) as a DILEMMA.

Ogbulu and Emeni (2012) studied the capital structure and firm value of 124 companies quoted on the Nigerian Stock Exchange (NSE) for the year ended 31 ${ }^{\text {st }}$ December, 2007 using OLS method of regression to analyse the data. The result of the study reveals that equity capital as a component of capital structure is irrelevant to the value of a firm, while long-term debt was found to be the major determinant of firm value.

Onaolapo and Kajola (2010) examine the impact of capital structure on firm's financial performance using sample of thirty non-financial firms listed on the Nigerian Stock Exchange during the period, 2001-2007. OLS method of estimation was used to analyse the panel data which were generated. The result of the study shows that a firm's capital structure surrogated by debt ratio has a significantly negative impact on the firm's financial measures, proxy by Return on Asset and Return on Equity.

The result of an investigation of the effect of capital structure on the performance of conglomerate firms quoted on the Nigerian Stock Exchange from 2011-2015, by Ubesie (2016) indicates that capital structure has effect on the dependent variables proxy by ROE and EPS of the conglomerates. The study used descriptive statistics and pooled ordinary least square 
(POLS) regression analytical method of data analysis. Mutalib (2010) examines the determinants of capital structure in Nigerian cement industry for the period 2000-2009 using time series data of four listed cement firms. The ordinary least square method of analysis was used to analyse the effect of eight exogenous variables (tangibility of assets, firm size, growth, profitability, earnings volatility, age of firm, liquidity and current year leverage value) on capital structure. The result of the study shows that profitability, size of the firm, liquidity and lag of leverage are negatively significantly related to leverage whereas potential of growth, age of the firm tangibility are positively significantly related with the leverage ratio. The prediction of pecking-order theory was proved in the case of profitability where as earnings volatility fails to confirm the trade-off theory.

Babalola (2014) studied 31 manufacturing firm listed in Nigeria using their audited financial statements for the period 1999-2013 from static trade-off point of view. The study used the triangulation analysis and the result reveals that capital structure is a trade-off between the costs and benefits of debt. The research by Agha (2015) on capital structure determinants and their relationships on listed firms of Pakistan cement industry for the period 2008-2013 using panel least square method of regression analysis shows that the independent variables including liquidity, profitability and cost of debt have a significant impact and negatively related with debt ratio, implying that if the variables increase, debt ratio will decrease. The study also reveals that tax and growth variables have significant impact and a positive relationship, implying that if these variables increase debt ratio will decrease. Three other variables used in the study (size, tangibility and dividend) have no significant impact on debt ratio, meaning that there would be no impact of any change occurring in these variables on debt ratio.

Anarfo (2016) examines the relationship between capital structure and bank performance in sub-Sahara Africa for the period 2000-2006. The study employed the use of panel data techniques to analyse the relationship between capital structure and bank performance proxy by ROA, ROE and NIM. Total debt ratio was the proxy for capital structure. The results from the unit root tests show that all the variables were stationary in levels. The results further indicate that capital structure of banks in Sub-Sahara Africa is statistically insignificant, implying that capital structure does not have much impact on bank performance, that is, the bank's performance does not depend on its capital structure, rather it is capital structure that depends on a bank's performance. It was also found that size is an important determinant of total debt ratio and asset tangibility is an important determinant of bank performance but does not carry the expected signs in the ROA and ROE. Tax rate and inflation were found to be significant in determining only the NIM; however, growth rate of banks, size and the GDP growth rate are not significant in determining banks performance in Sub-Sahara Africa.

Khanam, Nasreen and Pirzada (2014) examined the impact of capital structure on firm's financial performance of the food sector of Pakistan from 2017 - 2012. Four independent variables (debt-equity ratio, debt to total assets ratio, short-term debt to total assets ratio and long-term debt to total assets ratio) were studied. Using linear regression to analyse secondary data obtained from published audited annual financial reports of sample cement firms, the results indicate that capital structure has significant negative impact on return on equity (ROE), net profit margin (NPM), return on capital employed (ROCE) and return on assets (ROA). The impact on earnings per share (EPS) was insignificantly negative.

Tifow and Sayilir (2015) evaluate the relationship between capital structure and firm performance using a sample of 130 manufacturing firms listed on Borsa Istanbul Stock 
Exchange from 2008-2013. Short-term debt to total assets and long-term debt to total assets were used as proxies of financial leverage. ROE, ROA, Earnings Per Share and Tobin's Q ratio were used for performance, while sales growth and firm size were used as control variables. Findings of the study show that short-term debt (STDA) has a significant negative relationship with ROE, EPS and Tobin's Q ratio, while long-term debt (LTDA) has a significant negative relationship with ROE, EPS and Tobin's Q ratio but positively and significantly correlated with ROA.

Frank et al (2002) analysed the outcome of the researches conducted in different countries having different lawful environment. Their analysis shows that capital structure determinants are more or less comparable across America and European countries. However, this is not $100 \%$ similar and some differences are also found across Dutch, French and English countries due to their different legal environment. But debt and equity planning or strategies are almost more or less the same between Dutch and French countries with different lawful system. The result of the research by Ebaid (2009) indicates that capital structure has weak-to-no influence of the financial performance of listed firms in Egypt. By using three accounting-based measurements of financial performance which are Return on Asset (ROA), Return on Equity (ROE), and Gross Margin (GM), the result of the empirical tests shows that capital structure (particularly short-term debt and total debt) has negative impact on organisation's financial performance measured by ROE and GM. The study of seven European countries by Weill (2007) to find the relationship between capital structure and firm performance shows that in Spain and Italy, the relationship is significant and positive while it is negative in Germany, France, Belgium and Norway but insignificant in Portugal. Campello (2006) argues that firms with moderate level of long term debt, as in market, will face an increase in sales, but firms with higher levels of debt standard will not have significant growth in sales or in market.

\section{Data Collection}

\section{RESEARCH METHODOLOGY}

To achieve the objective of the study, data was collected from the secondary source by going through various web sites and audited annual financial reports, specifically, Income Statement and Statement of Financial Position (reported in accordance with IFRS and GAAP) of selected cement companies in Nigeria for the period 2006 - 2015. The companies studied comprise four cement companies whose audited annual financial reports for the period of study were available. They are Lafarge WAPCO Cement, Cement Company of Northern Nigeria (CCNN), Ashaka Cement, and Dangote Cement Plc. The data for the study is presented in fig. 3.1 below: 
Ogbulu, M. O., Okanta, S. U., \& Turakpe, M. J. (2018). Capital Structure And Corporate Financial Performance: Evidence From Nigerian Cement Companies. Archives of Business Research, 6(3), 222-244.

Table3.1Nigeria:Data from audited annual financial reports of cement companies,2006-2015,in $\%$

\begin{tabular}{|c|c|c|c|c|c|c|c|c|c|c|}
\hline Company & Year & ROE & ROA & ROS & TDA & LDA & EQA & ATO & TAST & TSAL \\
\hline \multirow{10}{*}{ WAPCO } & 2006 & 50.82 & 15.01 & 32.84 & 38.10 & 10.52 & 46.91 & 5.61 & 17.53 & 17.49 \\
\hline & 2007 & 35.28 & 20.52 & 29.95 & 41.52 & 8.91 & 51.80 & 6.29 & 17.80 & 17.47 \\
\hline & 2008 & 29.10 & 19.61 & 28.03 & 34.50 & 5.20 & 65.50 & 7.01 & 17.94 & 17.58 \\
\hline & 2009 & 18.94 & 9.50 & 18.20 & 49.89 & 37.61 & 50.15 & 5.03 & 18.28 & 17.64 \\
\hline & 2010 & 17.05 & 6.95 & 18.72 & 59.24 & 10.23 & 40.76 & 3.70 & 18.59 & 17.60 \\
\hline & 2011 & 15.24 & 5.64 & 13.83 & 63.19 & 42.08 & 36.81 & 4.08 & 18.84 & 17.95 \\
\hline & 2012 & 2.11 & 9.21 & 16.09 & 54.98 & 34.12 & 44.74 & 5.74 & 18.84 & 18.28 \\
\hline & 2013 & 3.02 & 17.52 & 28.84 & 42.05 & 17.45 & 57.94 & 6.08 & 18.89 & 18.39 \\
\hline & 2014 & 10.25 & 8.14 & 26.67 & 19.48 & 8.85 & 80.52 & 3.08 & 19.66 & 18.48 \\
\hline & 2015 & 9.80 & 7.8 & 20.69 & 20.64 & 7.53 & 77.49 & 3.0 & 19.76 & 18.56 \\
\hline \multirow{10}{*}{ CCNN } & 2006 & 28.66 & 21.58 & 11.97 & 36.0 & 14.51 & 43.81 & 82.42 & 22.33 & 22.49 \\
\hline & 2007 & 24.28 & 20.33 & 12.61 & 38.21 & 17.32 & 49.22 & 98.61 & 22.69 & 22.57 \\
\hline & 2008 & 29.67 & 18.65 & 18.52 & 44.10 & 12.53 & 56.80 & 96.55 & 22.28 & 22.69 \\
\hline & 2009 & 34.60 & 25.10 & 21.51 & 43.26 & 18.11 & 54.32 & 112.10 & 22.53 & 23.21 \\
\hline & 2010 & 36.50 & 21.16 & 15.96 & 45.16 & 15.12 & 59.21 & 106.52 & 23.16 & 23.66 \\
\hline & 2011 & 47.03 & 26.17 & 23.47 & 44.28 & 14.33 & 55.19 & 110.74 & 23.25 & 23.36 \\
\hline & 2012 & 21.60 & 11.59 & 11.26 & 46.36 & 10.52 & 53.65 & 106.25 & 23.38 & 23.44 \\
\hline & 2013 & 21.74 & 13.08 & 12.48 & 39.82 & 11.71 & 60.16 & 104.80 & 23.44 & 23.48 \\
\hline & 2014 & 20.30 & 12.16 & 12.70 & 40.14 & 18.0 & 59.89 & 95.82 & 23.48 & 23.44 \\
\hline & 2015 & 11.84 & 7.0 & 9.21 & 40.84 & 16.26 & 59.13 & 76.03 & 23.57 & 23.29 \\
\hline \multirow{10}{*}{ DANGOTE } & 2006 & 20.68 & 16.72 & 30.16 & 37.81 & 16.74 & 59.72 & 46.80 & 19.10 & 17.58 \\
\hline & 2007 & 20.01 & 18.52 & 33.59 & 36.52 & 14.88 & 60.32 & 48.32 & 19.29 & 17.36 \\
\hline & 2008 & 24.77 & 20.24 & 29.01 & 38.81 & 13.65 & 58.72 & 47.72 & 19.63 & 17.94 \\
\hline & 2009 & 33.24 & 21.52 & 36.40 & 43.16 & 14.55 & 63.66 & 50.21 & 19.54 & 18.68 \\
\hline & 2010 & 50.40 & 23.60 & 53.0 & 44.17 & 18.62 & 63.21 & 46.88 & 19.81 & 19.13 \\
\hline & 2011 & 38.46 & 21.08 & 45.76 & 43.90 & 22.71 & 54.58 & 46.0 & 20.08 & 19.30 \\
\hline & 2012 & 35.44 & 23.40 & 51.05 & 33.97 & 14.02 & 66.03 & 45.67 & 20.25 & 19.47 \\
\hline & 2013 & 36.71 & 25.63 & 56.61 & 30.37 & 12.08 & 69.76 & 45.37 & 20.53 & 19.73 \\
\hline & 2014 & 29.11 & 19.29 & 51.35 & 33.75 & 12.36 & 66.25 & 38.53 & 20.68 & 19.74 \\
\hline & 2015 & 28.47 & 18.96 & 53.85 & 33.45 & 20.91 & 66.55 & 34.61 & 20.84 & 19.78 \\
\hline \multirow{10}{*}{ ASHAKA } & 2006 & 29.70 & 18.28 & 20.14 & 31.11 & 5.23 & 62.89 & 90.78 & 17.11 & 15.98 \\
\hline & 2007 & 18.32 & 7.13 & 13.33 & 36.10 & 8.44 & 69.81 & 88.20 & 17.81 & 15.71 \\
\hline & 2008 & 19.24 & 6.05 & 14.61 & 35.52 & 16.31 & 76.70 & 86.75 & 17.68 & 15.56 \\
\hline & 2009 & 12.95 & 5.89 & 13.22 & 34.26 & 17.12 & 73.32 & 63.71 & 18.21 & 15.91 \\
\hline & 2010 & 10.71 & 6.32 & 14.81 & 36.21 & 15.69 & 83.60 & 49.31 & 18.15 & 16.62 \\
\hline & 2011 & 6.17 & 5.33 & 13.94 & 34.0 & 14.16 & 85.85 & 38.71 & 17.81 & 16.85 \\
\hline & 2012 & 6.31 & 5.41 & 14.22 & 30.85 & 14.21 & 85.78 & 37.83 & 17.87 & 16.90 \\
\hline & 2013 & 5.99 & 4.72 & 13.01 & 34.0 & 20.94 & 78.89 & 36.35 & 17.90 & 16.89 \\
\hline & 2014 & 8.91 & 7.26 & 21.63 & 32.02 & 19.01 & 81.04 & 33.28 & 17.96 & 16.87 \\
\hline & 2015 & 5.21 & 3.93 & 16.15 & 24.72 & 14.15 & 75.40 & 24.75 & 18.07 & 16.67 \\
\hline
\end{tabular}

Source: Computed from audited annual financial reports of studied cement companies, 2006 2015

\section{Variables of the Study}

The study used three types of variables. These are financial performance as dependent variable measured by Return on Equity (ROE), Return on Asset (ROA) and Return on Sales (ROS). Capital structure as independent variable is measured by Total debt/Assets (TDA), Long-term debt/Assets (LDA) and Equity/Assets (EQA). The control variables which also affect firm financial performance are Asset utilization measured as Assets-Turnover ratio (ATO) and the size of the firm measured as logTotal Assets (TAST) and logTotal sales (TSAL).

The table below shows the details of variables used in the study. 
Table 3.2 Details of Variables

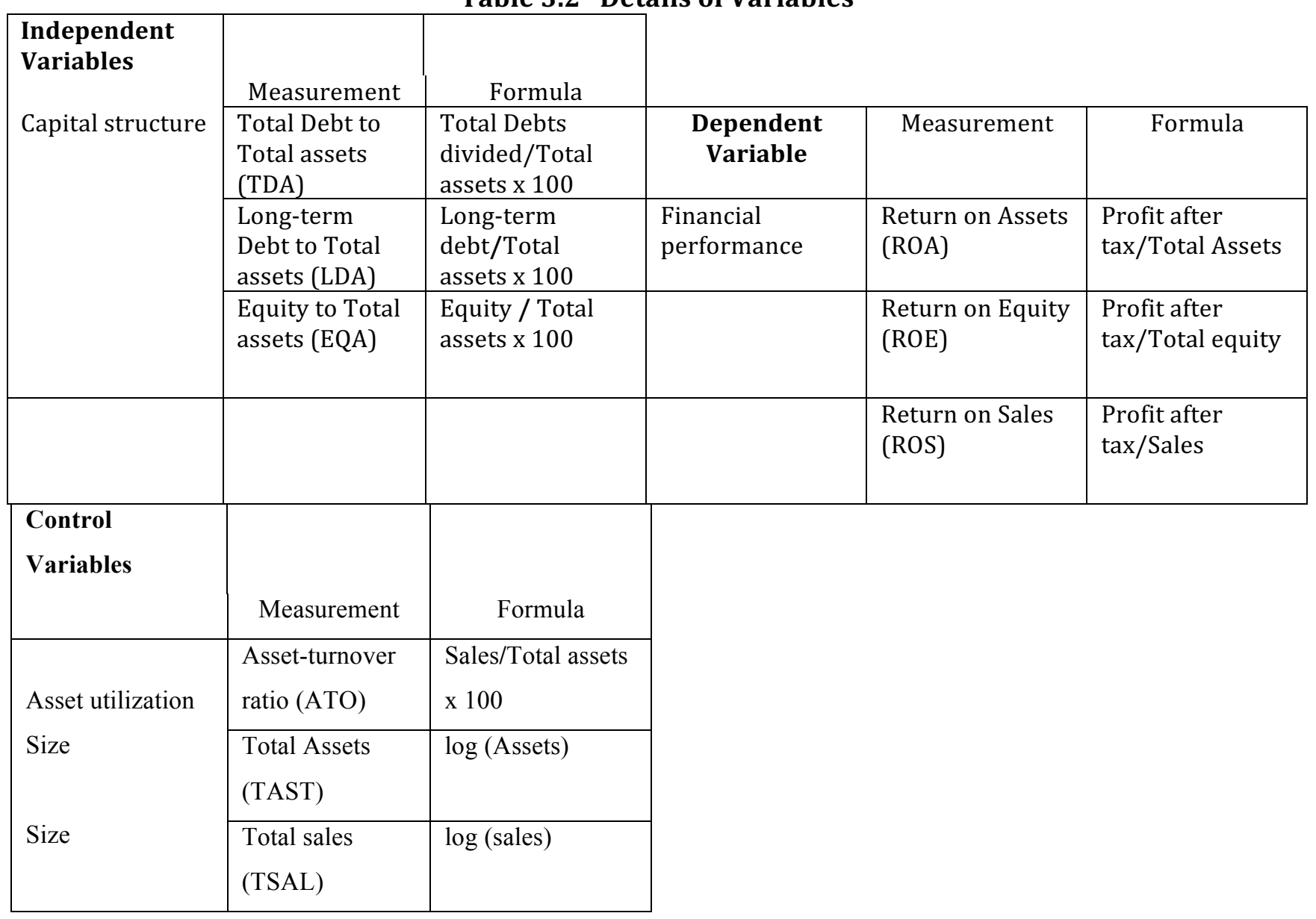

The control variables are treated as explanatory variables.

\section{Conceptual model}

Following the works of Singh and Singh (2016), Park and Jang (2013), Nirajini and Priya (2013) Noor and Suarchi (2015), and Javed, Younas and Imran (2014), we conceptually model our study thus: 


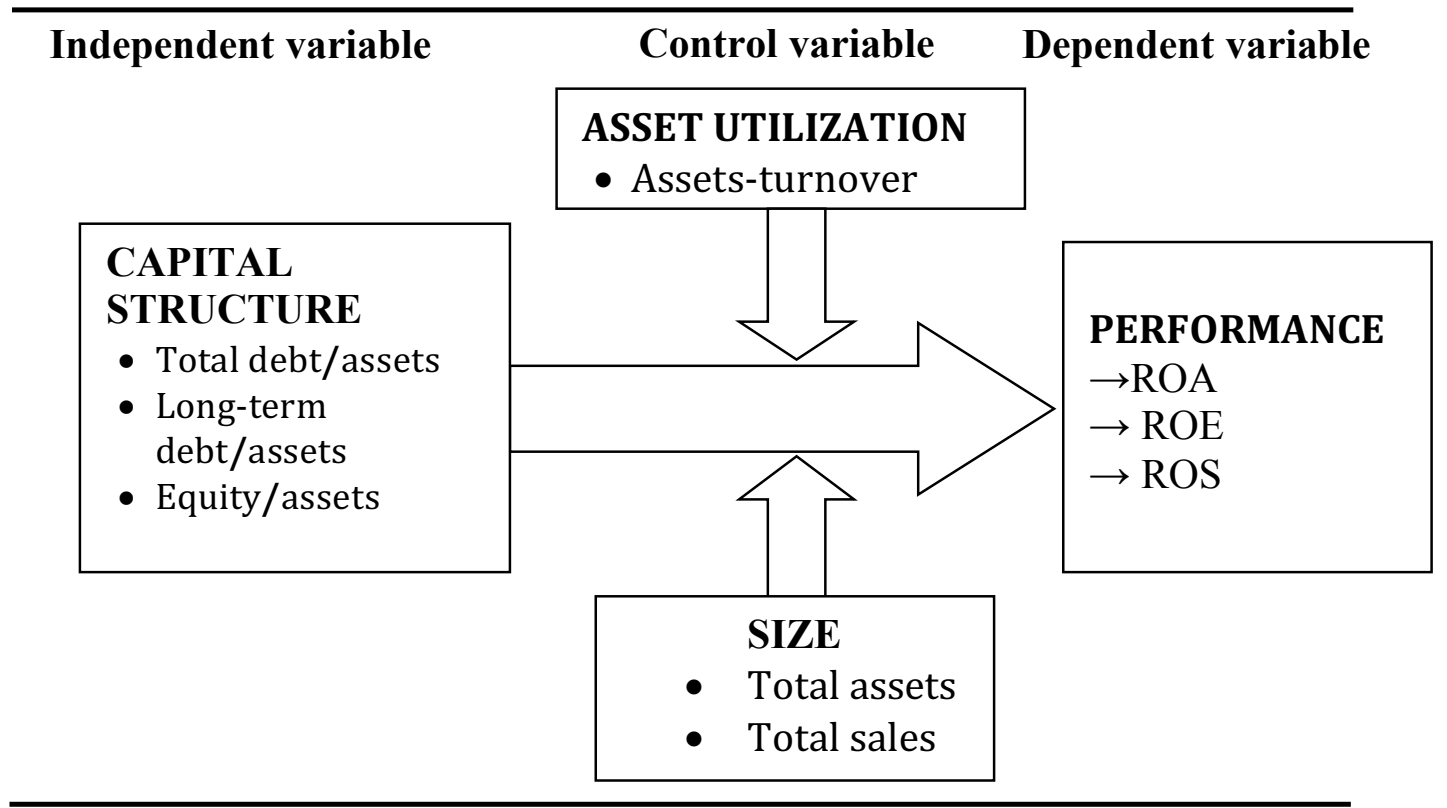

Fig. 3.1 Researchers' Conceptual Model

Fig.3.1 tells us that the firms' performance is a function of capital structure subject to such control variables of asset size and utilization. The concepts are expressed in the model specifications (see 3.4).

\section{Model specification}

The relationship between capital structure and financial performance using linear regression equation is given as

$$
\operatorname{PERF}=\beta_{o}+\beta C S+e_{t}
$$

Where PERF = financial performance measures

$\mathrm{CS}=$ capital Structure

$\mathrm{e}_{\mathrm{t}}=$ the error term

Econometric transformation of equation (1) above for all of the three measurements of dependent variable is given as:

$$
\begin{aligned}
& R O A=\beta_{o}+\beta_{1} T D A+\beta_{2} L D A+\beta_{3} E Q A+\beta_{4} A T O+\beta_{5} T A S T+\beta_{6} T S A L+e_{t} \\
& R O E=\beta_{o}+\beta_{1} T D A+\beta_{2} L D A+\beta_{3} E Q A+\beta_{4} A T O+\beta_{5} T A S T+\beta_{6} T S A L+e_{t} \\
& R O S=\beta_{o}+\beta_{1} T D A+\beta_{2} L D A+\beta_{3} E Q A+\beta_{4} A T O+\beta_{5} T A S T+\beta_{6} T S A L+e_{t}
\end{aligned}
$$

Where $\beta_{0}, \beta_{1}$ $\beta_{6}$, are the model parameter (slope)

ROA = Return on assets, expressed in percent as a measurement of financial performance. $\mathrm{ROE}=$ Return on equity expressed in percent as a measurement of financial performance ROS = Return on sales, expressed in percent as a measurement of financial performance. TDA = Total debt over asset ratio, expressed in percent, as a measurement of capital structure. LDA = Long-term debt over asset ratio, expressed in percent, as a measurement of capital structure.

$\mathrm{EQA}=$ Equity over asset ratio, expressed in percent, as a measurement of capital structure. ATO $=$ Sales over asset ratio, control variable, a measurement of asset utilization .

TAST = Natural logarithm of total asset, control variable, a measurement of firm size.

TSAL = Natural logarithm of total sales, control variable, a measurement of firm size. 


\section{Method of Data Analysis}

The study used regression model to test the influence of capital structure on financial performance of cement companies in Nigeria. Method of Ordinary Least Square (OLS) and Autoregressive Distributed Lags (ARDL) approach were adopted in this study to regress and to investigate the long-run equilibrium (cointegration) among variables. OLS is used because it minimizes the error between the estimated points on the line and the actual observed points of the estimated regression line by giving the best fit. This method is in line with other researchers like Ogbulu and Emeni (2012), Onaolapo and Kajola (2010), Chowdhury and Chowdhury (2010), Muritala (2012), and Park and Jang (2013) who all used multiple regression analysis in their studies.

\section{Autoregressive Distributed Lag (ARDL) or Bounds Test}

Autoregressive Distributed Lag (ARDL) or bounds test which is initially proposed by Pesara and Shin (1998), is an alternative cointegration technique which is used for determining cointegrating relationship in small samples unlike the Johansen cointegration technique which may require large data samples for the purpose of validity (Ghatak and Saddiki, 2001). Unlike other cointegrating techniques, which require all of the regressors to be integrated of the same order, ARDL can be applied whether the regressors are I(1) and I(0) or mix of both (ie. whether the results are of order 1 or order zero stationary). It avoids the pre-testing problems associated with standard cointegration, which require that variables are already classified I(1) or I(0). It also avoids the optimal number lags to be specified, implying that with ARDL, it is possible that different variables have different optimal number of lags. An ARDL model incorporates the lagged values of the independent variables among the set of explanatory variable (Gujarati \& Porter 2009).

\section{Descriptive Statistics}

\section{RESULT}

Table 4.1 Descriptive Statistics

\begin{tabular}{|c|c|c|c|c|c|c|c|c|c|}
\hline & ROE & ROA & ROS & TDA & LDA & EQA & ATO & TAST & TSAL \\
\hline Mean & 22.71575 & 14.40000 & 24.48475 & 38.66150 & 15.91725 & 62.65200 & 50.98100 & 19.86400 & 19.09350 \\
\hline Median & 21.14000 & 15.86500 & 19.43000 & 37.95500 & 14.53000 & 60.24000 & 46.40000 & 19.41500 & 18.33500 \\
\hline Maximum & 50.82000 & 26.17000 & 56.61000 & 63.19000 & 42.08000 & 85.85000 & 112.1000 & 23.57000 & 23.66000 \\
\hline Minimum & 2.110000 & 3.930000 & 9.210000 & 19.48000 & 5.200000 & 36.81000 & 3.000000 & 17.11000 & 15.56000 \\
\hline Std. Dev. & 12.98146 & 7.151326 & 13.64980 & 8.791056 & 7.583664 & 12.60659 & 36.52253 & 2.065694 & 2.610806 \\
\hline Skewness & 0.340405 & 0.002645 & 1.101408 & 0.484382 & 1.778668 & 0.103096 & 0.226491 & 0.617612 & 0.648302 \\
\hline Kurtosis & 2.387274 & 1.492116 & 3.046371 & 4.112536 & 6.728064 & 2.337157 & 1.784762 & 1.982403 & 2.034039 \\
\hline Jarque-Bera & 1.398224 & 3.789572 & 8.090908 & 3.627069 & 44.25516 & 0.803126 & 2.803327 & 4.268803 & 4.357101 \\
\hline Probability & 0.497026 & 0.150351 & 0.017502 & 0.163077 & 0.000000 & 0.669273 & 0.246187 & 0.118315 & 0.113206 \\
\hline Sum & 908.6300 & 576.0000 & 979.3900 & 1546.460 & 636.6900 & 2506.080 & 2039.240 & 794.5600 & 763.7400 \\
\hline Sum Sq. Dev. & 6572.214 & 1994.517 & 7266.361 & 3014.024 & 2242.966 & 6198.120 & 52021.92 & 166.4166 & 265.8361 \\
\hline Observations & 40 & 40 & 40 & 40 & 40 & 40 & 40 & 40 & 40 \\
\hline
\end{tabular}

\section{Source: E-view Result}

Table 4.2 shows the summary of the descriptive statistics of sample study. From the above results, number of total observations is 40 and mean value of return on equity is 22.7, return on assets has a mean of 14.4, return on sales show a good return with a mean value of 24.5, mean value of debt to assets ratio, which is an independent variable and determines capital structure, is about 38.7, long term debt to asset's mean is 15.9 , equity to asset ratio which is again independent variable has a mean value of 62.7, assets-turnover ratio has a mean value of about 60, natural log of total assets and that of total sales which both measure firm's size are 
19.7 and 19.1 respectively. Standard Deviation for ROE is 12.9, ROA is 7.2, ROS is 13.6, and for TDA, LDA, EQA, ATO, TAST, and TSAL are 8.8, 7.6, 12.6, 36.5, 2.1 and 2.6 respectively.

Skewness is positive for return on equity, return on assets, return on sales, total debt over assets ratio, long term debt over assets ratio, equity over asset ratio, assets-turnover ratio, natural log of total assets and that of total sales, implying that the data is positively skewed because extreme values are to the left. Kurtosis is used to show the peak or flatness of the data. There are three types of kurtosis: platykurtic distribution, which shows low degree of peak or flatness; normal or mesokurtic distribution which shows normal distribution curve; and leptokurtic distribution which shows high peak of the data. If kurtosis is less than 3 then it is a platykurtic distribution, if it is equal to 3 then it is a mesokurtic distribution and if kurtosis shows values more than 3 then it is a leptokurtic distribution. Total debt over assets ratio and long term debt over assets ratio have kurtosis values more than 3, which show leptokurtic distribution. Return on sales has kurtosis value of 3 which shows mesokurtic distribution, while return on assets, return on equity, equity over assets ratio, assets-turnover ratio, natural log of total assets and that of total sales have kurtosis value less than 3, which reveals flatness of data and it is platykurtic distribution. The p-values of Jarque-Bera indicate that all the variables are normally distributed except Return on Sales, and Long-term debt to asset ratio which are not.

\section{Correlation}

Table 4. 3 Correlation Matrix

\begin{tabular}{|c|c|c|c|c|c|c|c|c|c|}
\hline & ROE & ROA & ROS & TDA & LDA & EQA & ATO & TAST & TSAL \\
\hline ROE & 1.000000 & & & & & & & & \\
\hline ROA & 0.803810 & 1.000000 & & & & & & & \\
\hline ROS & 0.554330 & 0.619113 & 1.000000 & & & & & & \\
\hline TDA & 0.157079 & 0.083060 & -0.145073 & 1.000000 & & & & & \\
\hline LDA & -0.211747 & -0.197666 & -0.087124 & 0.575628 & 1.000000 & & & & \\
\hline EQA & -0.383540 & -0.376938 & 0.014809 & -0.765078 & -0.343300 & 1.000000 & & & \\
\hline ATO & 0.296272 & 0.293699 & -0.282360 & 0.031089 & -0.221390 & -0.047020 & 1.000000 & & \\
\hline TAST & 0.303715 & 0.420973 & -0.058671 & 0.174895 & -0.035032 & -0.338100 & 0.656773 & 1.000000 & \\
\hline TASL & 0.355484 & 0.460667 & -0.069517 & 0.233540 & -0.022691 & -0.406212 & 0.609587 & 0.977891 & 1.000000 \\
\hline
\end{tabular}

\section{Source: E-view Result}

The correlation matrix in table 4.3 shows the degree of correlation between the variables. The table reveals that the variables among themselves have both positive and negative correlations and there is no serious problem of multicollinearity found in this research study. Although two correlation values are greater than 0.80 which show multicollinearity, it is ignored and acceptable in panel data analysis.

\section{Data Analysis and Findings}

The empirical results of the OLS simple regression estimated on the level series data for the three models are presented in table 4.3 below: 


\section{OLS ESTIMATIONS}

Table 4.3 Summary results of level series OLS multiple regression

\begin{tabular}{|c|c|c|c|c|c|c|}
\hline \multirow{2}{*}{ Variables } & \multicolumn{2}{|c|}{ MODEL 1 (ROA) } & \multicolumn{2}{|c|}{ MODEL 2 (ROE) } & \multicolumn{2}{|c|}{ MODEL 3 (ROS) } \\
\hline & $\begin{array}{l}\text { Coefficient } \\
\text { (Std. error) }\end{array}$ & $\begin{array}{c}\text { t-statistic } \\
\text { (Prob.) }\end{array}$ & $\begin{array}{l}\text { Coefficient } \\
\text { (Std. error) }\end{array}$ & $\begin{array}{c}\text { t-statistic } \\
\text { (Prob.) }\end{array}$ & $\begin{array}{l}\text { Coefficient } \\
\text { (Std. error) }\end{array}$ & $\begin{array}{c}\text { t-statistic } \\
\text { (Prob.) }\end{array}$ \\
\hline Intercept & $\begin{array}{c}44.50899 \\
(24.41432)\end{array}$ & $\begin{array}{l}1.823069 \\
(0.0774)\end{array}$ & $\begin{array}{c}95.68369 \\
(45.19197)\end{array}$ & $\begin{array}{c}2.117272 \\
(0.0419)\end{array}$ & $\begin{array}{r}9.535065 \\
(53.91293)\end{array}$ & $\begin{array}{c}0.176860 \\
(0.8607)\end{array}$ \\
\hline TDA & $\begin{array}{c}-0.273846 \\
(0.21180)\end{array}$ & $\begin{array}{c}-1.292925 \\
(0.2050)\end{array}$ & $\begin{array}{l}-0.224584 \\
(0.392057)\end{array}$ & $\begin{array}{c}-0.572835 \\
(0.5706)\end{array}$ & $\begin{array}{c}-0.268612 \\
(0.467714)\end{array}$ & $\begin{array}{c}-0.574308 \\
(0.5697)\end{array}$ \\
\hline $\begin{array}{c}{[} \\
{[[[]} \\
{[} \\
\text { LDA }\end{array}$ & $\begin{array}{c}-0.158474 \\
(0.172509)\end{array}$ & $\begin{array}{c}-0.918640 \\
(0.3649)\end{array}$ & $\begin{array}{l}-0.431557 \\
(0.319322)\end{array}$ & $\begin{array}{c}-1.351482 \\
(0.1857)\end{array}$ & $\begin{array}{c}-0.239606 \\
(0.380943)\end{array}$ & $\begin{array}{c}-0.628982 \\
(0.5337)\end{array}$ \\
\hline EQA & $\begin{array}{l}-0.318610 \\
(0.137237)\end{array}$ & $\begin{array}{c}-2.321604 \\
(0.0266)\end{array}$ & $\begin{array}{l}-0.528350 \\
(0.254032)\end{array}$ & $\begin{array}{c}-2.079861 \\
(0.0454)\end{array}$ & $\begin{array}{l}-0.166407 \\
(0.303054)\end{array}$ & $\begin{array}{c}-0.549099 \\
(0.5866)\end{array}$ \\
\hline ATO & $\begin{array}{c}0.027359 \\
(0.039385)\end{array}$ & $\begin{array}{c}0.694656 \\
(0.4921)\end{array}$ & $\begin{array}{l}-0.096557 \\
(0.072903)\end{array}$ & $\begin{array}{l}1.324456 \\
(0.1945)\end{array}$ & $\begin{array}{c}-0.182902 \\
(0.086972)\end{array}$ & $\begin{array}{c}-2.10994 \\
(0.0432)\end{array}$ \\
\hline TAST & $\begin{array}{c}-1.974170 \\
(2.576166)\end{array}$ & $\begin{array}{c}-0.766321 \\
(0.4489)\end{array}$ & $\begin{array}{c}-5.952632 \\
(4.768595)\end{array}$ & $\begin{array}{c}-1.248299 \\
(0.2207)\end{array}$ & $\begin{array}{c}5.609577 \\
(5.688819)\end{array}$ & $\begin{array}{c}0.986071 \\
(0.3313)\end{array}$ \\
\hline TSAL & $\begin{array}{c}2.135932 \\
(1.998080)\end{array}$ & $\begin{array}{l}1.068992 \\
(0.2928)\end{array}$ & $\begin{array}{c}4.661623 \\
(3.698532)\end{array}$ & $\begin{array}{c}1.260398 \\
(0.2164)\end{array}$ & $\begin{array}{c}-3.274932 \\
(4.412259)\end{array}$ & $\begin{array}{c}-0.742235 \\
(0.4632)\end{array}$ \\
\hline R-Squared & \multicolumn{2}{|c|}{0.377168} & \multicolumn{2}{|c|}{0.352365} & \multicolumn{2}{|c|}{0.166431} \\
\hline Adjusted $\mathrm{R}^{2}$ & \multicolumn{2}{|c|}{0.263925} & \multicolumn{2}{|c|}{0.234613} & \multicolumn{2}{|c|}{0.014767} \\
\hline F-statistic & \multicolumn{2}{|c|}{3.330625} & \multicolumn{2}{|c|}{2.992436} & \multicolumn{2}{|c|}{1.097422} \\
\hline Prob(F-statistic & \multicolumn{2}{|c|}{0.011235} & \multicolumn{2}{|c|}{0.019070} & \multicolumn{2}{|c|}{0.384606} \\
\hline Durbin-Watson & \multicolumn{2}{|c|}{0.774458} & \multicolumn{2}{|c|}{0.759031} & \multicolumn{2}{|c|}{0.451340} \\
\hline Observations & \multicolumn{2}{|c|}{40} & \multicolumn{2}{|c|}{40} & \multicolumn{2}{|c|}{40} \\
\hline
\end{tabular}

Source: Author's compilation from E-view results

In table 4.3 above, we have the results of the level series multiple regression models as specified in equations (1), (2) and (3). From the regression results of the three models (ROA, ROE and ROS), Durbin-Watson (DW) statistic for the three models are $0.77,0.76$ and 0.45 respectively. These indicate the presence of positive autocorrelation in the estimated models, and the stronger the closer the DW statistic is to zero (Koutsoyianis, 1977). This may render the estimated results unreliable for both analysis and policy formulation, suggesting the need for more rigorous analysis of the stationarity properties of the level series data (Ogbulu, 2010). The presence of auto-correlation in the level series multiple regression estimates provides a firm justification for the Autoregressive Distributed Lag (ARDL) tests that were carried out and reported in tables $4.4,4.5$ and 4.6 below: 


\section{Autoregressive Distributed Lag (ARDL) Estimations}

Model 1 Return on asset (ROA) as a dependent variable

Table 4.4 Autoregressive Distributed Lag (ARDL) Results

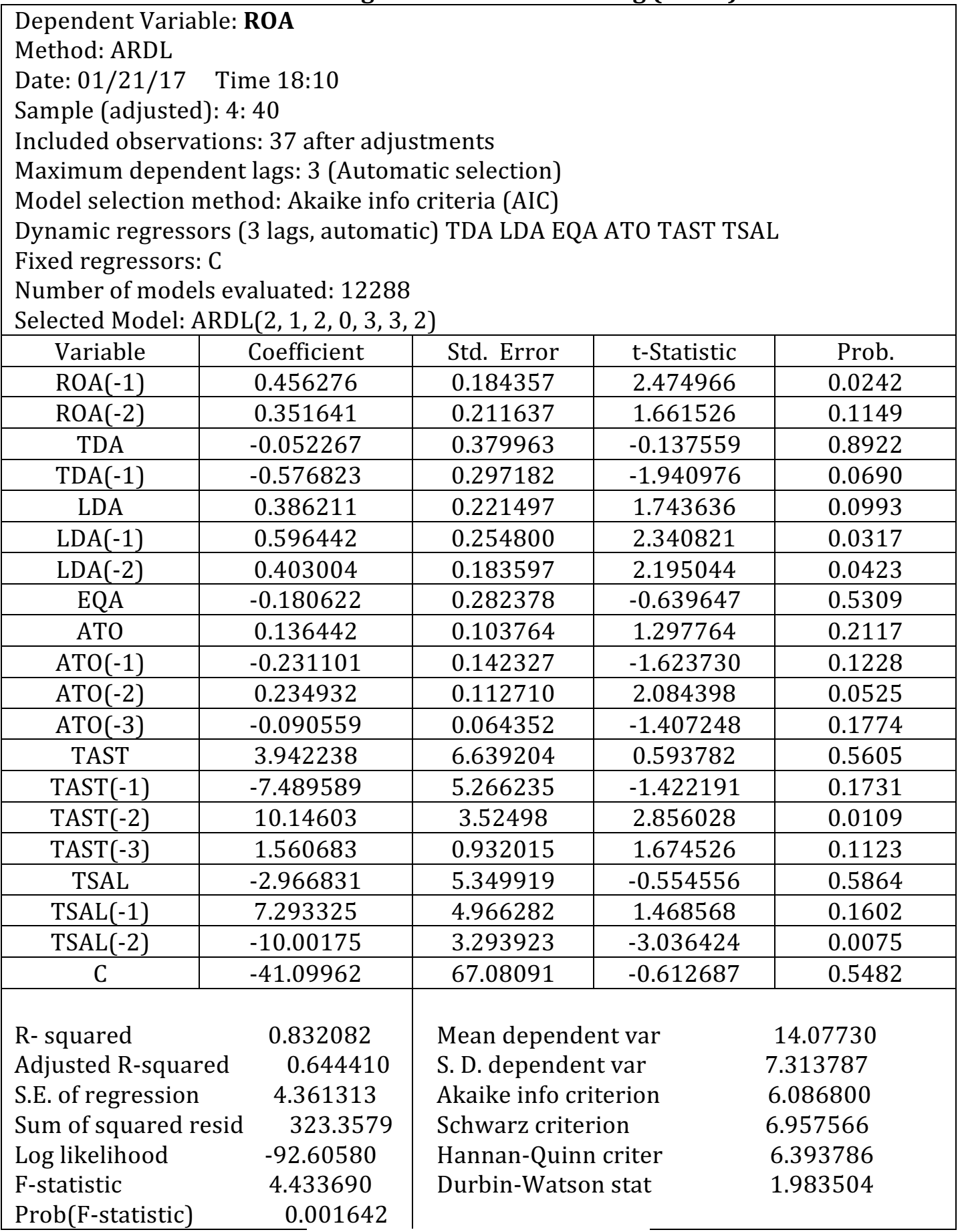

Source: E-view result

Table 4.4 presents the results of the ARDL test for the impact on ROA of independent variables representing capital structure, namely, Total Debt to Asset ratio (TDA), Long-term Debt to Asset ratio (LDA), Equity to Asset ratio (EQA), Asset- Turnover ratio (ATO) and Total Asset (TAST) and Total Sales (TSAL) both representing firm size. The results indicate that TDA, EQA and TSAL are all negatively related to ROA. It can be concluded that an increase in debt, equity will cause a decrease in a firm's performance. Only the one-period lags of TDA and TSAL have significant relationship with ROA. LDA exerts a positive and significant relationship with ROA, 
while ATO and TAST have positive but insignificant relationship with ROA. The one and two period lags of LDA are significantly related while only the two-period lags of ATO and TAST have significant relationship.

The overall result reveals that R-squared is 0.83 and adjusted R-squared is 0.64 indicating that $83 \%$ of the variations in ROA could be explained by the combined effects of changes in the explanatory variables. The model is a good fit with the F-statistic value and its P-value if 4.433690 and 0.001642 respectively. The Durbin-Watson statistic value is approximately 2.0 indicating the absence of any auto-correlation in the ARDL model, implying that the model results presented in table 4.5 are obviously better than the level series multiple regression results in table 4.1. 


\section{Model 2 Return on equity (ROE) as a dependent variable}

Table 4.5 Autoregressive Distributed Lag (ARDL) Results

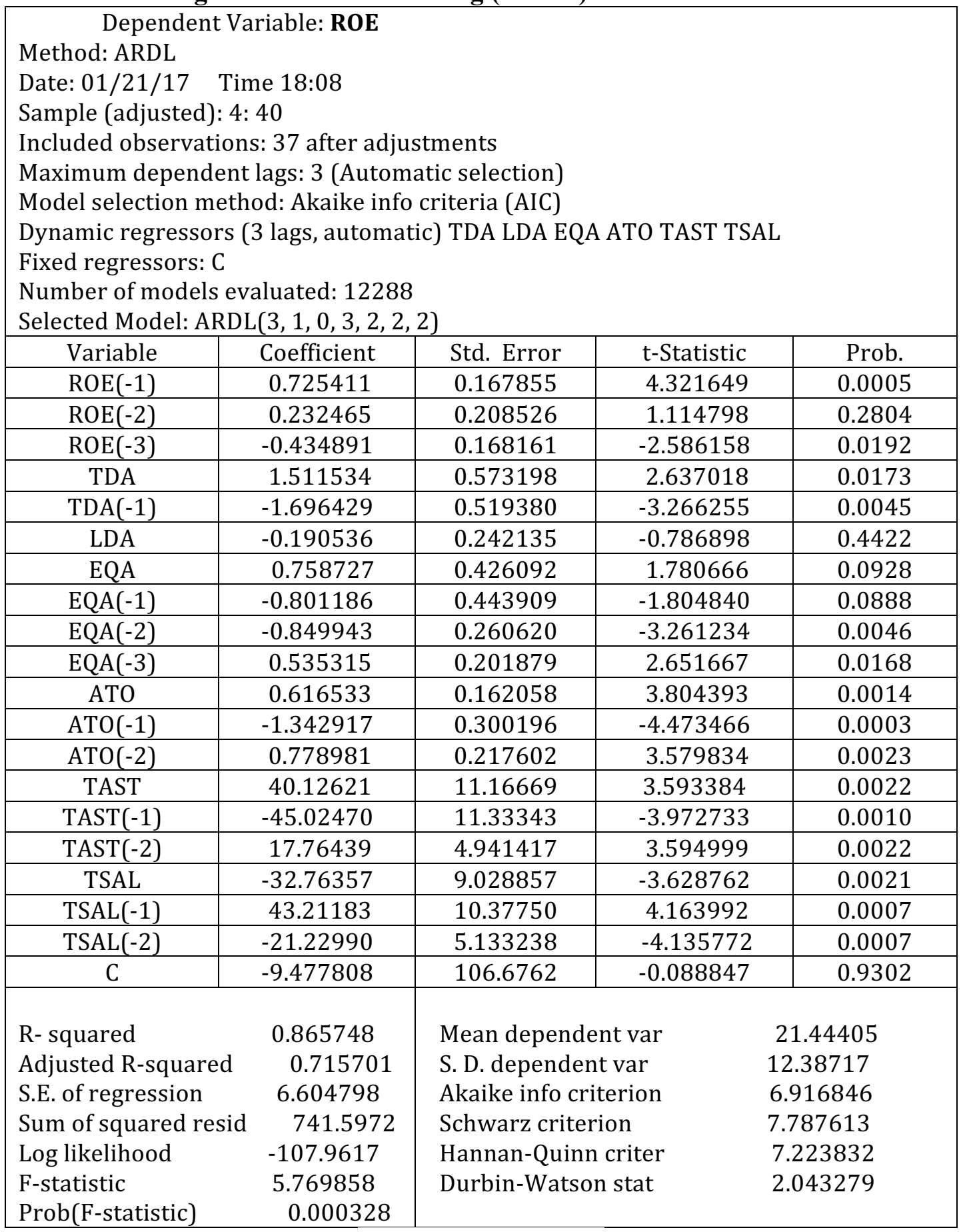

\section{Source: E-view result}

The ARDL results in table 4.5 indicate a goodness of fit with an F-ratio of 5.769858 and probability of 0.000328 . $\mathrm{R}^{2}$ is $86.6 \%$ and the adjusted $\mathrm{R}^{2}$ is $71.6 \%$, meaning that the model explains that approximately $86.6 \%$ of the changes in ROE are attributable to the combined effect of total debt to asset ratio (TDA), long-term debt to asset ratio, (LDA) equity to asset ratio (EQA), asset-turnover ratio, (ATO) firm total sales (TSAL) and total asset (TAST). The DW statistic value of 2.043279 indicates the absence of any auto-correlation in the model. 
From the above result, total debt to asset (TDA) exerts a positive and significant impact on return on equity (ROE) while its one- period lag has negative coefficient but also significantly impacts on ROE; long-term debt to asset ratio (LDA) has a negative and insignificant relationship with ROE, equity to asset ratio (EQA) has a positive and significant relationship with ROE, while its one and two-period lags are all negatively significantly related to ROE. Total asset-turnover ratio (TAST) and its two-period lag exert positive and significant relationship with ROE, while its one-period lag is negative but still statistically significant.

Total asset (TAST), which coefficient is negative except the one-period lag, exerts positive and significant relationship with ROE, while firm's Total sales (TSAL) negatively and significantly relates to ROE. Thus, as in model 1, long term debt to asset ratio (LDA) appears not to have any significant impact on return on equity of cement companies in Nigeria. Total debt to asset ratio has positive and significant impact over return on asset. 


\title{
Model 3 Return on sales (ROS) as a dependent variable
}

Table 4.6 Autoregressive Distributed Lag (ARDL) Results

\author{
Method: ARDL
}

Dependent Variable: ROS

Date: $01 / 21 / 17$ Time 18:11

Sample (adjusted): $4: 40$

Included observations: 37 after adjustments

Maximum dependent lags: 3 (Automatic selection)

Model selection method: Akaike info criteria (AIC)

Dynamic regressors (3 lags, automatic) TDA LDA EQA ATO TAST TSAL

Fixed regressors: $\mathrm{C}$

Number of models evaluated: 12288

Selected Model: ARDL(1, 0, 0, 0, 3, 3, 2)

\begin{tabular}{|c|c|c|c|c|}
\hline Variable & Coefficient & Std. Error & t-Statistic & Prob. \\
\hline ROS $(-1)$ & 0.790078 & 0.106419 & 7.434563 & 0.0000 \\
\hline TDA & 0.182312 & 0.557101 & 0.327252 & 0.7467 \\
\hline LDA & -0.055233 & 0.259056 & -0.213209 & 0.8332 \\
\hline EQA & 0.082357 & 0.470519 & 0.175034 & 0.6827 \\
\hline ATO & -0.234807 & 0.160308 & -1.464726 & 0.1578 \\
\hline ATO $(-1)$ & -0.101951 & 0.239065 & -0.426490 & 0.6741 \\
\hline $\operatorname{ATO}(-2)$ & 0.427667 & 0.180899 & 2.364125 & 0.0278 \\
\hline $\operatorname{ATO}(-3)$ & -0.290740 & 0.105295 & -2.761202 & 0.0117 \\
\hline TAST & 8.952118 & 10.38119 & 0.862340 & 0.3982 \\
\hline TAST $(-1)$ & -14.75041 & 8.460699 & -1.743404 & 0.0959 \\
\hline TAST(-2) & 17.96124 & 5.945657 & 3.020900 & 0.0065 \\
\hline TAST $(-3)$ & 1.739644 & 1.590493 & 1.039777 & 0.2864 \\
\hline TSAL & -6.365554 & 8.393391 & -0.758401 & 0.4566 \\
\hline TSAL $(-1)$ & 13.41891 & 7.837486 & 1.721035 & 0.1016 \\
\hline TSAL(-2) & -15.80782 & 5.396154 & -.2 .929461 & 0.0080 \\
\hline $\mathrm{C}$ & -105.6211 & 106.9484 & -0.987585 & 0.3346 \\
\hline R-squared & 0.818801 & \multicolumn{2}{|c|}{ Mean dependent var } & 24.01541 \\
\hline Adjusted R-squared & 0.689388 & \multicolumn{2}{|c|}{ S. D. dependent var } & 14.08897 \\
\hline S.E. of regression & 7.852149 & \multicolumn{2}{|c|}{ Akaike info criterion } & 7.257921 \\
\hline Sum of squared resid & 1294.781 & \multicolumn{2}{|c|}{ Schwarz criterion } & 7.954534 \\
\hline Log likelihood & -118.2715 & \multicolumn{2}{|c|}{ Hannan-Quinn criter } & 7.703510 \\
\hline F-statistic & 6.326672 & \multirow{2}{*}{\multicolumn{2}{|c|}{ Durbin-Watson stat }} & 2.110975 \\
\hline Prob(F-statistic) & 0.000080 & & & \\
\hline
\end{tabular}

Source: E-view result

The adjusted $\mathrm{R}^{2}$ of model 3 (table 4.6 ) is 0.818809 , indicating that approximately $82 \%$ of the variation in return on sales (ROS) is explained by the independent (capital structure) variables. Again, the F-statistic of 6.3266772 and P-value of 0.000080 indicate that the model is a good fit. The Durbin-Watson statistic value of 2.110925 suggests the absence of out-correlation in the model.

Furthermore, coefficient of TDA and EQA are positive and insignificant while the coefficient of LDA and ATO are negative and also insignificant. This result shows that one unit of change in TDA and EQA would lead to positive change in ROS. At lags 2 and 3, ATO is significant just like TAST at lags 1 and 2 with negative and positive coefficient respectively at both lags. TSAL has negative and statistically insignificant relationship with ROS at lag 1; TSAL is positive and not significant while at lag 2 , its coefficient is negative and significant. 


\section{DISCUSSION OF FINDINGS}

The study's findings are in line with Ebaid (2009) and Saeedi and Mahmoodi (2011) who found negative relationship between total debt/assets ratio and long-term debt with ROA. Gansuwan and Önel(2012) for the Swedish firms found significant negative relations between ROA and TDA. Olokoyo (2012) also found a significant and negative impact of TDTA on ROA in Nigeria. In Albania, Cekrezi(2013), finds that TDA negatively impacts on the ROA. The results of Salteh et al. (2012) in Iran indicate a negative relation with ROA. In Pakistan, according to Umar et al. (2012), the results show that TDA negatively impacts on the ROA. In Bangladesh, according to Hasan et al.(2014), the results show significant negative relation between ROA and TDA. Since ROA measures management's ability to utilize the firm's assets to generate revenue, it is expected that the ROA, in this study, will have a significant positive relationship with ATO, due to the fact that higher leverage may lead managers to utilize the firm's assets more efficiently since they have an extra obligation to meet debt-holders' expectations (Abu-Rub,2012).

Previous studies by Nirajini and Priya (2013) and Parte and Jang (2013) have also shown positive relationship between total debt to asset ratio and return on asset. It is indicative that, for any increment in total debt ratio, all things being equal, profit of the sampled cement firms in Nigeria shall also increase correspondingly and vice-versa. The agency cost theory hypothesis asserts that to reduce agency cost and force the managers to act more in the interest of the owners, higher total debt than equity should be introduced in firm's capital structure. If the ratio of debt is higher in firm's capital structure, the fear of liquidation, debt servicing, insolvency which may result to loss of job to the mangers, will lead to a reduction in the cost, lead to efficiency and finally improve the firm's performance. From the study, cement companies in Nigeria should use more debt to increase their profitability. The findings of ARDL estimation in table 4.6 are consistent with Al-Taani (2013), Onaolapo and Kajola (2010), Pratheepkanth (2011) and Voulgaris et al (2001).

\section{CONCLUSION AND REMARKS}

The study investigates the impact of capital structure on financial performance of cement companies in Nigeria using three accounting based measures of performance (ROA, ROE and ROS). Due to the problem of autocorrelation in the panel data, the study employed the Autoregressive Distributed Lag (ARDL) method also known as Bound test, to estimate the parameters. The regression results reveal that all the explanatory variables except ATO and TAST, have mixed relationship with firm performance indicators used in the study, hence capital structure variables (Total Debt to Asset ratio, Long-term debt to Asset ratio and Equity to Asset ratio) are found to have mixed impact on financial performance of Nigerian cement companies. This result finds robust support in earlier studies by scholars like Ogbulu and Emeni (2012), Khannam, Nasereen and Pirzada (2014), Tifow and Sayilir (2015), Ebaid (2009), Compellow (2006), Psillaki (2007), and Muritala (2013).

Modigliani and Miller (1958) had earlier stated in their theory of capital structure irrelevance that if other things remain constant, then capital structure does not have impact on firm performance. The fact remains that practically in Nigerian economy and the world today, it is impossible to hold all things constant. The observed mixed relationship between debt and equity, and performance proxies used in the study could be explained by the higher cost of debt and strong covenants attached to the use of debt due to lack of well developed equity and debt ( long-term debt) market in Nigeria. This is supported by Amjed (2011) who asserts that the reason could be attributed to the longer duration of debt, underdeveloped debt market and high required rate of return on debt. The study also reveals that efficient utilization of assets is an important factor that impacts on the financial performance of cement firms in Nigeria rather than using different sources of funds. 
The study recommends that although mixed relationship between capital structure and financial performance of cement companies in Nigeria was found, managers should be careful while it is necessary to use debt as a source of finance. They should rather finance their operations with retained earnings and use debt and equity, in that order, as the last options as supported by the Pecking order theory.

\section{References}

Abor, J. (2005). The effect of capital structure on firm performance: an empirical analysis of listed firms in Ghana, Journal of Risk Finance, Vol.2, 438-447.

Abu-Rub, N. (2012). Capital Structure and firm performance; Evidence from Palestine Stock Exchange. Journal of Money, Investment and Banking, vol. 23: pp 109-117.

Agha, H. (2015), Determinants of capital structure of cement sector in Pakistan, European Scientific Journal, vol.11, pp. 353-367

Akinsurile, O. (2008). Financial Management. Lagos: Eltoda Ventures Ltd. 6th Edition

Al-Taani, K. (2013), The relationship between capital structure and firm performance: evidence from Jordan. Journal of Finance and Accounting; 1(3): 41-45.

Anarfo, E. B. (2015), Capital structure and bank performance: evidence from Sub-Sahara Africa, European Journal of Accounting, Auditing and Finance Research, vol. 3(3) pp. 1-20

Ang, J.S, Cole, R.A and Lin, J.W (2000): “Agency costs and ownership structure.” Journal of Finance, 55, pp 81- 106.

Aurangzeb, D. and Haq, A. (2012), Determinants of capital structure: A case from textile industry of Pakistan, International Journal of Academic Research in Business And Social Sciences, vol. 2 (4), pp. 408-421

Babalola Y. A. (2014). Triangulation Analysis of Capital Structure and Firms' Performance in Nigeria. East Ukrainian National University [Vol. Dahl] 91034, Lugansk, Ukraine

Boodhood, R. (2009), Capital structure and ownership structure: A review of literature, The Journal of Online Education, January edition, pp 1-8

Booth, L., Aivazian, V., Demirguc-Kunt, A., and Maksimovic, V. (2001), Capital structure in developing countries. Journal of Finance, 56(1), 87-130.

Brigham, E. and Gapenski, L. (1996), Financial Management. Dallas: The Dryden Press.

Campellow, M. (2006), Debt financing: does it boost or hurt firm performance in product markets? Journal of Financial Economics. 82, 135-172

Çekrezi, A. (2013), The Determinants of capital structure: Evidence from Albania, Academic Journal of Interdisciplinary Studies, Vol. 2, No. 9 pp 370 - 376

Chakravarthy, B. S., (1986), "Measuring Strategic Performance”, Strategic Management Journal vol.7, pp. 437-58.

Chechet, I. L. and Olayiwola, A. B. (2014), Capital structure and profitability of Nigerian quoted firms: The agency cost theory perspective, American International Journal of Social Science, vol. 3 (1);

Chowdhury,A. and Chowdhury, S. (2010), Impact of capital structure on firm's value: Evidence from Bangladesh Peer. Reviewed and Open Access Journal:, 1804-1205

Ebaid., E. I. 2009. The impact of capital structure choice on firm performance: empirical evidence from Egypt, Journal of risk Finance, Vol. 7, pp. 477-487.

Fama, E. F. and French, K. R. (1999), Taxes, Financing Decisions, and Firm Value, Journal of Finance, Vol. 53.

Frank, M., and Goyal, V. (2003). Testing the pecking order theory of capital structure, Journal of Financial Economics. 67, 217-248

Gansuwan,P.,\& Önel,C.Y.(2012).The influence of capital structure on firm performance: A quantitative study of Swedish listed firms.Umeå Sweeden.

Ghatak, S. and Siddike, J. (2001), The use of the ARDL approach in estimating virtual exchange rates in India, Journal of Applied Statistics, vol. 28:573-583.

Gitman, L. (2009), Principles of Managerial Finance , (12 ed.) The Addison Wesley 
Gorton, G. and R. Rosen (1995), Corporate control, portfolio choice, and the decline of McGraw-Hill.

Hasan, B., Ahsan, A. F. M., Rahaman, A. and Alam, N. (2014), Influence of capital structure on firm performance: Evidence from Bangladesh, International Journal of Business and Management 9(5):184-194

Hillier, D., Jaffe, J., Jordan, B., Ross, S. \& Westerfield, R. (2010). Corporate Finance. Berkshire: McGraw-Hill Education.

Hoffer, C. W., and Sandberg, W. R. (1987), Improving new venture performance: Some guidelines for success, American Journal of Small Business, vol. 12, pp.11-25.

Javed, T., Youna, W. and Imran, M. (2014), Impact of capital structure on firm performance: Evidence from Pakistani firms, nternational Journal of Academic Research in Economics and Management Sciences, Vol. 3, pp.28-52

Jensen, M. C. and Meckling, W. H. (1976), Theory of the firm: managerial behavior, agency costs and ownership structure, Journal of Financial Economics, vol. 3, pp. 305-360.

Khanam, F., Nasreen, S. and Pirzada, S. S. (2014), Impact of capital structure on firm's financial performance: Evidence from food sector of Pakistan, Research Journal of Finance and Accounting, Vol.5, No.11, pp 93 - 105

Koutsoyiannis, A. (1977), Theory of econometrics: An introductory exposition of econometric methods, 2nd ed. London, The Macmillan press ltd.

Kraus, A. and Litzenberger, R. (1973), A state-preference model of optimal financial leverage, The Journal of Finance, vol. 28, pp. 911-921.

Lee, C. and Hsiesh, M. (2013), Impact of bank capital on profitability and risk in Asian banking. Journal of International Money and Finance, 251-281.

Margaritis, D. and Psillaki, M. (2007), Capital structure and firm efficiency, Journal of Business Finance \& Accounting, vol. 34(9-10), pp. 1447-1469

Mehran, H. (1995), Executive compensation structure, ownership, and firm performance, Journal of Financial Economics, 38, pp. 163-184.

Mitan, H. ( 2014), Capital structure and competitive position in product market. International Review of Economics and Finance, vol.29, pp. 358-371.

Modigliani, F. and Miller, M. H. (1958), The and the Theory of Investment, The American economic review, vol. 48, pp. 261-297

Modigliani, F. and Miller, M. H. (1963), Corporate income taxes and the cost of capital: A correction. The American Economic Review, 53 (3), pp. 433-443.

Muritala, A. T. ( 2012), An empirical analysis of capital structure on firms' performance in Nigeria. International journal of advances in management and economics, 2278-3369.

Murphy, G. B., J. W. Trailer, and R. C. Hill, (1996), Measuring performance in entrepreneurship research, Journal of Business Research, 36, 15-23.

Mutalib, A. (2010), Determinants of capital structure in the Nigerian cement industry: A study of selected firms, Nigerian journal of accounting research, Vol.6, (1), pp 118-129

Myers, S. C. (1993), Still searching for optimal capital structure, Journal of Applied Corporate Finance, vol. 6 (1), pp 4-14

Myers, S. C. (1984), The capital structure puzzle, The Journal of finance, vol. 39, pp. 575 - 592.

Myers, S. C. and Majluf, M. S. (1984), Corporate Financing and Investment Decisions when Firms have Information that Investors do not have, Journal of Financial Economics, vol. 13, pp. 18 7-221.

Nirajini, A. and Priya_K, B. (2013), Impact of capital structure on financial performance of the listed trading companies in Sri Lanka, International Journal of Scientific and Research Publications, Vol. 3, pp. 2250-3153.

Noulas, N. and Genimakis, G (2001), The determinants of capital structure choice: Evidence from Greek listed companies, Applied financial economics, 21,379-387.

Ogbulu, O. M. and Emeni, F. K. (2012), Capital structure and firm value: Empirical evidence from Nigeria, International journal of business and social science, vol. 3(19) pp. 252-261

Ogbulu, O.M. (2010), “The interaction between inflation, interest rates and stock returns in nigeria: Test of Fisher's Hypothesis”, International Journal of Accounting, Finance \& Economic Perspectives, A Publication of the International Academy of Business and Behavioral Sciences, CT, USA. Vol. 2, No. 2, Fall, pp. 69-86. 
Olayinka, A. (2011), Determinants of capital structure: Evidence from Nigerian panel data, African Economic and Business Review, Vol. 9, No.1, pp. 1-16.

Olokoyo, F. O. (2012). Capital Structure and Corporate Performance of Nigerian Quoted Firms. A Panel Data Approach. Published PhD Thesis presented to the Department of Banking and Finance, School of Business, College of Development Studies, Covenant University, Ota, Ogun State Nigeria.

Onaolapo, A. A. and Kajola, S. O. (2010), Capital structure and firm performance: evidence from Nigeria, European Journal of Economics, Finance and Administrative Sciences, I25, 70-77.

Park, K. and Jang, S. (2013), Capital structure, free cash flow, diversification and firm performance: A holistic analysis. International journal of hospitality management, 33, 51-63.

Pesarau, M. H. Shin, Y. (1998), Generalized impulse-response analysis in linear multivariate models. Economics letter, vol. 58(1), pp.17-29.

Pesaran, M.H, Shin, Y. and Smith, R. (2001), Bounds tests approaches to the analysis of level relationships, Journal of Applied Economy, vol.16. pp. 289-326

Pratheepkanth, P. (2011), Capital structure and financial performance: evidence from selected business companies in Colombo Stock Exchange, Sri Lanka, Journal of arts, science and commerce, vol. 2(2), pp171-173

Rauh, J. D. and Sufi, A. (2010) Capital Structure and Debt Structure. The review of financial studies, 23 (12), pp. 4242-4280.

Rose, S. A.; Weserfield, R. W. and Jaffe, J. F. (2005), Corporate Finance, $6^{\text {th }}$ ed.; Homewood Irwin

Saeedi, A \& Mahmoodi I, (2011), Capital Structure and Firm Performance: Evidence from Iranian Companies, International Research Journal of Finance and Economics, 70: 21-28.

Salteh, H. M., Ghanavati, E., Khanqah, V. T. and Khosroshahi, M. A. (2012), Capital structure and firm performance:

Evidence from Tehran stock exchange. International Proceedings of Economics Development \& Research, 43: 225-30.

San, O. T. and Heng, T. B. (2011), Capital structure and corporate performance of Malaysia construction sector, International journal of humanities and social sciences, vol. 1 (2), pp. 8-36

Shamshur, A. (2012). Essays on capital structure stability. Center for Economic Research and Graduate Education Charles University Prague

Singh, B. and Singh, M. (2016), Impact of capital structure on firm's profitability: A study of selected listed cement companies in India, Pacific business review international, vol.8(7), pp 46-54.

Simerly, R. and Li, M. (2000), "Environmental dynamism, financial leverage and performance: a theoretical integration and an empirical test", Strategic Management Journal, Vol. 21, pp. 31- 49.

Stiglitz, J. E. and Weiss, A. (1981), Credit rationing in markets with imperfect information, American economic review, vol. 70, pp. 393-410.

Tifow, A. A. and Sayilir, O.(2015), Capital structure and firm performance, Eurasian Journal of Business and Management, 3(4), 13-22

Ubesie, M. C. (2016), The effect of capital structure on the financial performance of Nigerian quoted conglomerates,

European Journal of Accounting, Auditing and Finance Research, Vol.4, No.6, pp.61-69

Umar, M., Tanveer, Z., Aslam, S, and Sajid. M (2012). Impact of capital structure on firm's financial Performance: Evidence from Pakistan. Research Journal of Finance and Accounting, vol.3: No. 9. pp 1-12

Voulgaris, F., Asteriou, D. \& Agiomirigianakis, G. (2001), Capital structure, assets utilization, profitability and growth in the Greek manufacturing sector. Applied Economics, 1379-1388.

Weill, L. (2007), Leverage and Corporate Performance: Does Institutional Environment Matter? Small Business Economics, 30:251-265. 